\title{
Sosyal Bilgiler Öğretmen Adaylarının Tablo, Grafik ve Diyagram Çizme ve Yorumlama Becerisine İlişkin Görüşleri ${ }^{*}$
}

\author{
Esen DURMUŞ \\ Doç. Dr., Fırat Üniversitesi, \\ Eğitim Fakültesi, Sosyal Bilgiler Eğitimi Bölümü \\ esendurmus@firat.edu.tr \\ Orcid ID: https//orcid.org/0000-0003-1011-8785

\section{Dilan KURUYER} \\ Arş. Gör., Kilis 7 Aralık Üniversitesi, \\ Eğitim Fakültesi, Sosyal Bilgiler Eğitimi Bölümü \\ dilankuruyer@kilis.edu.tr \\ Orcid ID: https//orcid.org/ 0000-0001-8145-5311
}

\section{Öz}

$\mathrm{Bu}$ araştırmanın amacı, sosyal bilgiler öğretmen adaylarının tablo, grafik ve diyagram çizme ve yorumlama becerisine ilişkin görüşlerini belirlemektir. Araştırmada nitel araştırma türlerinden olan durum çalışması deseni kullanılmıştır. Araştırma, 2019- 2020 eğitim- öğretim yılında 36 kadın, 14 erkek olmak üzere toplam 50 öğretmen adayı ile birlikte; Fırat Üniversitesi, İnönü Üniversitesi, Kilis 7 Aralık Üniversitesi, Muş Alparslan Üniversitesi ve Tokat Gaziosmanpaşa Üniversitesi Eğitim Fakültelerinde öğrenim gören 4. Sınıf sosyal bilgiler öğretmen adayları ile yürütülmüştür. Araştırmada verilere yarı yapılandırılmış görüşme formu ile ulaşılmış ve verilerin analizinde içerik analizi tekniği kullanılmıştır. Veriler, NVIVO 11 nitel veri analiz programı ile çözümlenmiştir. Öğretmen adaylarının söz konusu beceri için genellikle sayısal verilerin görsellerle ifade edilmesi şeklinde tanımlamalar yaptıkları tespit edilmiş ve bu becerinin kazandırılması konusunda sosyal bilgiler dersini yeterli gördükleri sonucuna ulaşılmıştır. Çalışmanın sonuçlarına göre, beceri eğitimi verilirken yöntem ve teknikler üzerinde daha fazla durulması önerilebilir.

\footnotetext{
${ }^{1}$ Makale Geliş/Kabul Tarihi: 11.09.2020 / 26.03.2021

* Bu makale "Sosyal Bilgiler Öğretmen Adaylarının Tablo, Grafik ve Diyagram Çizme ve Yorumlama Becerisine İlişkin Görüşleri" adlı yüksek lisans tezinden üretilmiştir. Künye Bilgisi: Durmuş, E. ve Kuruyer, D. (2021). Sosyal bilgiler öğretmen adaylarının tablo, grafik ve diyagram çizme ve yorumlama becerisine ilişkin görüşleri. Kahramanmaraş Sütçü İmam Üniversitesi Sosyal Bilimler Dergisi, 18 (1), 46-71. DOI: 10.33437/ksusbd.793809
} 
Anahtar Kelimeler: Sosyal bilgiler, Beceri eğitimi, Tablo, grafik ve diyagram çizme ve yorumlama becerisi.

\title{
The Opinions of Prospective Social Studies Teachers about Table-, Graph- and Diagram-Making and Interpretation Skills
}

\begin{abstract}
The aim of this research is to determine the opinions of prospective social studies teachers about table-, graph- and diagram-making and interpretation skills. The study employed the case study design- a type of the qualitative research design. The study group consisted of 50 4th year students, who were prospective social studies teachers, including 36 female and 14 male prospective teachers, studying at the Faculties of Education of Firat University, İnönü University, Kilis 7 Aralık University, Muş Alparslan University, and Tokat Gaziosmanpaşa University in Turkey in the academic year of 2019-2020. Data were collected through semi-structured interview forms, which were then analyzed by using the content analysis technique with NVIVO 11 software. It was found that the prospective teachers defined the skill as a way of expressing numerical data with visuals, and that they considered the social studies course sufficient to acquire the skill. According to the results of the study, it may be suggested to focus more on methods and techniques while providing skills training.
\end{abstract}

Keywords: Social studies, Skills training, Table-, graph- and diagram-making and interpretation skills

\section{GíRIŞ}

Geçmişten günümüze insanlık tarihi boyunca toplumsal yapıda birçok değişim yaşanmıştır. Günümüzde yaşanan değişim ise bilgi toplumlarında gelişmişlik göstergesi olarak kabul edilen bilginin hızlı bir şekilde toplumun her kesimine ulaşmasıyla beraber başlamıştır (Gürgil, 2019: 1). Bilgiye rahat bir şekilde ulaşabilen ve ulaştığı bilgiyi etkili bir biçimde kullanabilen bireyler yetiştirmeyi hedefleyen eğitim kurumlarının, bu hedeflere ulaşabilmesi için bireylere yaşadıkları çağa uyum sağlayabilmeleri için gerekli temel becerileri kazandırabilecek yapıya sahip olmaları gerekmektedir (Safi, 2010: 12). Bu hedefler doğrultusunda da bireylere ihtiyaç duydukları becerileri benimsetmeye yönelik eğitim programları oluşturulmaktadır (Seferoğlu ve Akbıyık, 2006: 193).

Beceri kavramı Türk Dil Kurumu tarafından "Elinden iş gelme durumu, ustalık maharet veya kişinin yatkınlık ve öğrenime bağlı olarak bir işi başarma ve bir işlemi amaca uygun olarak sonuçlandırma yeteneği, maharet" olarak tanımlanmaktadır (www. tdk.gov.tr, 2019). Birden çok tanımı olan beceri 
kavramına, son yıllarda çok daha önem verilmiş ve beceri kavramı öğretim programlarının temel yapı taşı haline gelmiştir. Sosyal bilgiler dersinde de beceriler ve beceri eğitimi önemli bir yere sahiptir (Erdoğan, 2019: 2000; Namal, 2019: 518; Türker, 2019: 54).

Eğitime büyük önem veren ülkemizde çağın gerekliliklerine ayak uydurabilmek ve donanımlı bireyler yetiştirebilmek için daha önce olduğu gibi 2005 ve 2018 yıllarında da öğretim programları güncellenmiştir. Temelinde etkin bireyler yetiştirme amaciyla yapılan bu değişiklikler, bireyin bilgi düzeyini ölçmekten daha çok, bireyin bu bilgiyi hayatında anlamlı bir şekilde kullanabilmesine odaklanmaktadır. 2005 öğretim programlarında becerilere ayrıntılı bir şekilde yer verilirken yine 2018 yılında yapılan bu değişiklikler ile eğitim faaliyetlerinin temel unsurlarından birinin beceriler olduğu görülmektedir (Namal, 2019: 518). Bu durum Sosyal Bilgiler Öğretim Programına da yansımıştır ve programda yeni becerilere yer verilmiştir. 2018 Sosyal Bilgiler Öğretim Programında yer alan beceriler aşağıdaki tabloda gösterilmiştir (MEB: 2018a).

Tablo 1. 2018 Sosyal Bilgiler Öğretim Programında Kazandırılması Hedeflenen Beceriler

\begin{tabular}{lll}
\hline 1. Araştırma & 10. Harita okuryazarlığı & 19.Mekânıalgılama \\
\hline 2. Çevre okuryazarlı̆̆ı & 11. Hukuk okuryazarlığı & 20. Öz denetim \\
\hline $\begin{array}{l}\text { 3. Değişim ve sürekliliği } \\
\text { algılama }\end{array}$ & 12. Illetişim & 21. Politik okuryazarlık \\
\hline $\begin{array}{l}\text { 4. Dijital okuryazarlık } \\
\text { 13. İ̧ birliği }\end{array}$ & 22. Problem çözme \\
\hline 5. Eleştirel düşünme & $\begin{array}{l}\text { 14. Kalıp yargı ve } \\
\text { önyargıyı fark etme }\end{array}$ & 23. Sosyal katılım \\
\hline 6. Empati & 15. Kanıt kullanma & $\begin{array}{l}\text { 24. Tablo, grafik ve diyagram } \\
\text { çizme ve yorumlama }\end{array}$ \\
\hline $\begin{array}{l}\text { 7. Finansal } \\
\text { okuryazarlık }\end{array}$ & 16. Karar verme & $\begin{array}{l}\text { 25. Türkçeyi doğru, güzel ve etkili } \\
\text { kullanma }\end{array}$ \\
\hline 8. Girişimcilik & 17. Konum analizi & 26. Yenilikçi düşünme \\
\hline 9. Gözlem & 18. Medya okuryazarlığı & 27. Zaman ve Kronolojiyi algılama \\
\hline
\end{tabular}

2005 Sosyal Bilgiler Öğretim Programında "tablo, diyagram ve grafik okuma becerisi”, mekânı algılama becerisinin alt becerileri arasında yer almıştır. $\mathrm{Bu}$ beceri 4. sınıf "Üretimden Tüketime" ünitesinde doğrudan verilecek beceri olarak yer alırken, 7. sınıf "Ülkemizde Nüfus" ünitesinde ise doğrudan verilecek beceriler arasında "grafik hazırlama becerisi" olarak verilmiştir. 2018 yılında yenilenen programla birlikte ise bu beceri Sosyal Bilgilerin kazandırmayı amaçladığ 1 beceriler arasında "tablo, grafik ve diyagram çizme ve yorumlama 
becerisi” olarak yerini almıştır. Söz konusu beceri 4. ve 7. sınıf "İnsanlar, Yerler ve Çevreler" öğrenme alanında kazandırılması amaçlanan becerilerden biridir. $\mathrm{Bu}$ ögrenme alanında bu beceri ile doğrudan ilişkili olan iki kazanım bulunmaktadır. 4. sinıfta "Çevresinde meydana gelen hava olaylarını gözlemleyerek bulgularını resimli grafiklere aktarır." kazanımıyla çizim becerisi üzerinde durulurken, 7. sınıfta ise "Türkiye'de nüfusun dağılışını etkileyen faktörlerden hareketle Türkiye'nin demografik özelliklerini yorumlar.” kazanımıyla yorumlama becerisi üzerinde durulmuştur.

Sosyal bilgiler, içinde bulundurduğu çeşitli disiplinlere ait kazanımları öğrencilere aktarmayı hedeflemekte ve hem sözel hem sayısal birçok bilgiyi içermektedir. Öğrencilere bu bilgileri aktarırken, öğrenme sürecini kolaylaştırmak ve kalıcı öğrenmeyi sağlamak için öğretim süreci içerisinde görsel araçlara sıklıkla başvurulmaktadır (Yazıcı, 2006: 651). Sosyal Bilgiler ve Coğrafya Öğretim Programlarında (MEB 2018a; MEB 2018b) bir beceri olarak yer alan bu görsel araçlar, fen bilimleri ve matematik gibi derslerde ise grafik düzenleyici olarak yer almaktadır. Dersin adı ne olursa olsun görsel araçlar her derse uygulanabilir ve öğrencinin dikkatini çekmesi, kalıcı öğrenmeyi sağlaması gibi avantajlarından dolayı öğrenci başarısına katkı sağlamaktadır. Bu çalışmada ise görsel araçlar, sosyal bilgiler dersi açısından beceri boyutuyla ele alınacaktır.

Sosyal bilgiler ders kitaplarında sıklıkla kullanılan tablo, grafik ve diyagramlar iki ya da daha fazla unsur arasındaki ilişkinin gösterilmesinde kullanılan en etkili eğitim materyalleridir. Bu materyaller öğrenciye, çok sayıda sözel ve sayısal bilgiyi simgesel formda sunarak hem zaman kazandırır hem de sayfalar dolusu yazıyı incelemekten kurtarır (Köse, 2011: 39).

Tablolar belli bir konudaki sayısal verileri ve sözel bilgileri daha sistemli bir şekilde sunan görsel araçlardır. Konuların özetlenmesi ve akılda kalıcılı̆̆ 1 açısından önemli olan tablolar hazırlanırken, öğrencinin seviyesine ve konunun öğretimine görsel açıdan uyup uymadığına dikkat edilmelidir. Tablolar sosyal bilgiler öğretiminde ekonomi, nüfus vb. birçok konuda kullanılabilir (Cendek, 2015: 17; Sönmez ve Koç, 2017: 192; Namal, 2019: 519). Öğrencilerin, bir tabloda yer alan bilgilerin artış- azalış miktarlarını ve sebep- sonuç ilişkilerini karşılaştırmalarını sağlayarak, beyin firtınası, tartışma, soru- cevap vb. yöntemteknikler aracılığıyla tablo çizme ve yorumlama becerisi geliştirilebilir.

Grafikler öğrencilere verilmek istenen sözel mesajların görselleştirilerek anlamlandırılması ve somutlaştırılmasında yaygın olarak kullanılan öğretim materyalleridir (Yanpar Şahin ve Yıldırım, 1999: 22). Sosyal bilgiler öğretiminde ekonomi ile ilgili konularda pasta grafikleri, çizgi grafikleri ve sütun grafikleri, nüfus ile ilgili konularda nüfus piramitleri, iklim konularında sıcaklık-yağış grafikleri kullanılabilir (Namal, 2019: 520). Çizgi grafikleri basit ve çoklu 
değişkenler arasındaki karşılaştırmaları, dönemsel değişimleri ve sık karşılaşılan durumları anlatmak için tercih edilirler. Sütun grafiklerinde ise sayısal verilerin yıllara göre değişimi gösterildiği gibi, tek bir y1la ait ilişkisel verilerin gösterimi de yapılabilmektedir. Daire grafikleri bir bütünü oluşturan parçaları göstermek ve bu parçalar arasında basit karşılaştırmalar yapmak için uygun öğretim materyalleridir. Nüfus piramitleri ise sosyal bilgiler eğitiminde demografik konuların öğretiminde tercih edilmektedir. Resim grafikleri de sayısal değerlerin veya basit düzeydeki çizimlerin resimlerle ifade edilmesidir.

Herhangi bir olayın verilerindeki değişmeyi, değişimin farklı aşamalarını gösteren diyagramlar, daha önceden hesaplanmış ya da gözlenmiş verilerin görsel şekiller durumuna getirilme tekniğidir (Doğanay, 2002: 264). Diyagramlar tabloların aksine daha özet ve az bilgi aktarır. Grafik ve tablolar gibi sadece sayısal ifadeleri değil, bir olayı veya olguyu da ifade edebilir (MEB, 2004). Sosyal bilgiler öğretiminde kullanılan diyagramlara örnek olarak blok diyagramlar, klimatik diyagramlar ve mevsim diyagramları verilebilir. Blok diyagramlar, bir sahanın yeryüzü şekillerini, topografik yapısını ya da jeolojik özelliklerini gösteren şekillerdir (Doğanay, 2002: 340). Klimatik diyagramlar ise rüzgârın esme sıklığı, esme sayısı ve yönlerine göre esme payları gibi özelliklerini gösteren şekillerdir (Meydan ve Akdağ, 2015: 168). Mevsim şeridi olarak da bilinen mevsim diyagramı ise mevsimleri ve ayları gösteren Sosyal Bilgiler eğitiminde özellikle ilk kademelerde çokça kullanılan görsel araçlardan biridir.

Alan yazın incelendiğinde grafik çizme ve yorumlama becerisiyle ilgili birçok çalışmaya rastlanmaktadır. Bayazıt (2011), Akgün (2010), Gültekin (2009) , Temiz ve Tan (2009), Yayla ve Özsevgeç (2014), Oruç ve Akgün (2010) ve Zorluoğlu ve Türkmen (2020) tarafından yapılan çalışmalarda öğrencilerin grafik yorumlama ve çizme düzeylerinin düşük olduğu tespit edilmiştir. Alan yazındaki bu çalışmalar dışında ülkemizin ilk olarak 2003 yılında katılmaya başladığ 1 uluslararası sınav olan PISA'nın 2015 ulusal raporunda, sinava Türkiye'den katılan öğrencilerin okuma becerileri, matematik okuryazarlığı ve fen okuryazarlığ 1 alanlarında ortalamanın altında kaldığ bu üç alanda öğrencilerin ortalamaya yakın başarı gösterdikleri ifade edilmektedir (MEB: 2016; MEB: 2019). Çiltaş (2011) bu durumun nedenleri arasında; eğitim sistemi, öğrenciler, öğretmenler, ders kitapları, ekonomik sıkıntılar ve öğretim sürecinde öğrencinin aktif katılımını gerektiren öğrenci merkezli yöntemlere gerektiğince yer verilmemesi gibi faktörlere vurgu yapmaktadır. Yine alan yazına baktığımızda; Bean, Singer, Sorter ve Frazee (1986), Alverman ve Boothby (1986), Taşdemir, Demirbaş ve Bozdağan (2005), Dönmez, Yazıcı ve Sabanc1 (2007), Şahin, Gençtürk ve Budanur (2007), Demirci ve Uyanık (2009), Zaini, Mokhtar ve Nawawi (2010), Akın Köse (2011), Namal (2011), Casteleyn ve Mottart (2012), Öztaşkın (2014), Keskin (2018) ve Gürgil 
(2018) ve tarafından çeşitli kademelerde öğrencilerle ve farklı derslerde yapılan çalışmalarda, genel olarak grafik düzenleyicilerinin, öğrencilerin akademik bilgilerini artırdığı ve grafik düzenleyicileriyle eğitim alan öğrenciler ile bu düzenleyiciler olmadan eğitim alan öğrencilerin başarı düzeyleri arasında anlamlı bir fark olduğu tespit edilmiştir. Bu durumda öğrencilere gerekli yöntemlerle grafik ve tablo gibi görsel araçları çizme ve yorumlama becerisi kazandırılırsa öğrencilerin bu alanda başarılarının artacağı görülmektedir. Dolayısıyla gelecekte öğrencilerin bu alanda becerilerini geliştirme sorumluluğunda olan öğretmen adaylarının TGDÇY becerisi ile ilgili görüşlerinin ne olduğu bu çalışmanın temel problemini oluşturmaktadır.

Sosyal Bilgiler Öğretim Programında yer alan birçok beceriden biri olan TGDÇY becerisine ilişkin yeterli düzeyde araştırmanın yapılmadığı ve genellikle grafik çizme ve yorumlama becerisine ilişkin nicel araştırmaların var olduğu söylenebilir. Ayrıca sosyal bilgilerde bu konunun beceri boyutuyla ele alındığı az sayıda çalışmaya rastlanmıştır. Nitel araştırmaların daha derine inmeyi ve daha detaylı bilgi toplamayı sağladığı düşünüldügünde yapılan bu çalışmanın alan yazına faydalı olacăğ beklenmektedir.

$\mathrm{Bu}$ araştırmanın temel amacı gelecekte öğretim programlarının uygulayıcısı olacak sosyal bilgiler öğretmen adaylarının görüșlerine başvurarak TGDÇY becerisini farklı bakış açılarıyla incelemektir. Bu amaca ulaşılabilmek için belirlenen alt amaçlar ise şöyledir:

- Öğretmen adayları beceri kavramını nasıl tanımlamaktadırlar?

- Öğretmen adayları TGDÇY becerisini nasıl tanımlamaktadırlar?

- Öğretmen adaylarının sosyal bilgiler dersinin bu beceriyi kazandırmadaki yeterliliğine ilişkin görüşleri nelerdir?

- Öğretmen adaylarının bu beceriyi kazandırırken kullanılabilecek yöntem ve tekniklere ilişkin görüşleri nelerdir?

- Öğretmen adaylarının bu beceriyi kazandırırken kullanılabilecek araçgereçlere ilişkin görüşleri nelerdir?

- Öğretmen adaylarının bu becerinin öğrenci başarısına etkisine ilişkin görüşleri nelerdir? 


\section{YÖNTEM}

\section{Araștırmanın Modeli}

Sosyal bilgiler öğretmen adaylarının TGDÇY becerisine ilişkin görüşlerinin belirlenmesinin amaçlandığ 1 bu araştırmada, nitel araştırma türlerinden biri olan durum çalışması deseni kullanılmıştır. Durum çalışması en temel özelliği bir ya da birden fazla durumun derinlemesine araştırılmasıdır (Yıldırım ve Şimşek, 2018, s: 73).

\section{Çalışma Grubu}

Araştırmanın çalışma grubunu, 2019-2020 eğitim-öğretim yılında Firat Üniversitesi, İnönü Üniversitesi, Kilis 7 Aralık Üniversitesi, Muş Alparslan Üniversitesi ve Tokat Gaziosmanpaşa Üniversitesi Eğitim Fakültelerinde öğrenim gören 4. Sınıf sosyal bilgiler öğretmen adayları oluşturmaktadır. Çalışma grubunda, gönüllülük esasına dayalı olarak seçilen 36 kadın ve 14 erkek olmak üzere toplamda 50 öğretmen adayı yer almaktadır. Araştırmanın çalışma grubu, amaçsal örneklemenin stratejilerinden biri olan kolay ulaş1labilir durum örneklemesine göre belirlenmiştir. Amaçsal örnekleme, çalışmanın amacına bağlı olarak bilgi açısından zengin durumların seçilerek derinlemesine araştırma yapılmasına olanak tanır (Büyüköztürk vd., 2018: 92). Kolay ulaşılabilir durum örneklemede ise araştırmacı, yakın olan ve erişilmesi kolay olan bir durumu seçer (Yıldırım ve Şimşek, 2018: 123). Bu çalışmaya ilişkin Fırat Üniversitesi Sosyal ve Beşeri Bilimler Araştırmaları Etik Kurulundan alınan 04/10/2019 tarih ve 351837 sayılı etik kurul izni bulunmaktadır. Öğretmen adaylarına ilişkin demografik bilgilere aşağıdaki tabloda yer verilmiştir.

Tablo 2. Öğretmen Adaylarına İlişsin Demografik Bilgiler

\begin{tabular}{lcc}
\hline Cinsiyet & F & $\%$ \\
Erkek & & \\
Kadın & 14 & 28 \\
Üniversite & 36 & 72 \\
Firat Üniversitesi & & \\
İnönü Üniversitesi & 10 & 20 \\
Kilis 7 Aralık Üniversitesi & 10 & 20 \\
Muş Alparslan Üniversitesi & 10 & 20 \\
Tokat Gaziosmanpaşa Üniversitesi & 10 & 20 \\
\hline
\end{tabular}




\section{Veri Toplama Aracı}

Nitel yöntemin kullanıldığı bu çalışmada verilere görüşme yoluyla ulaşılmıştır. Görüşmeler, kaynakların ulaşılabilirliğine ve araştırmada toplanmak istenen verilerin özelliğine göre farklı şekiller alabilir (Büyüköztürk vd., 2018: 158). $\mathrm{Bu}$ çalışmada ise ilgili konuda derinlere inebilmeyi sağlayan yarı yapılandırılmış görüşme tekniği kullanılmıştır (Ekiz, 2015: 63).

Yarı yapılandırılmış görüşme formu oluşturulmadan önce yurt içinde ve yurt dışında araştırma konusuyla ilgili çalışmalar taranmıştır. Alan yazın hakkında bilgi sahibi olunduktan sonra çalışmanın temel amacına yönelik sorular hazırlanmıştır. Bu sorular, uzmanlık alanı coğrafya ve sosyal bilgiler eğitimi olan iki farklı uzman tarafından değerlendirilmiş ve gerekli düzenlemeler yapıldıktan sonra altı sorudan oluşan görüşme formu oluşturulmuştur.

\section{Verilerin Analizi}

$\mathrm{Bu}$ çalışmada verilerin toplanmasına kaynaklık eden görüşmeler yüz yüze ve telefon aracılığıyla gerçekleştirilmiştir. Sözlü iletişim yoluyla veri toplama tekniği olan görüşme, çoğu zaman yüz yüze yapılıyor olsa da telefon gibi anında ses ve görüntü ileticileri ile de yapılmaktadır (Karasar, 2020: 210). Katılımcıların bilgisi doğrultusunda zaman kaybetmemek adına görüşmeler, hem kısa notlarla hem de ses kayıt cihazı aracılığıyla kayıt altına alınmıştır. Görüşmeler yaklaşık olarak 20-30 dakika arasında gerçekleşmiştir. Araştırmacı, aldığı notları görüşme sonunda katılımcıya özetleyerek doğruluğuna ilişkin bilgi almış ve daha sonra görüşme sonlandırılmıştır.

Araştırma sürecinde elde edilen verilerin analizinde içerik analizi tekniği kullanılmıştır. İçerik analizinde temel amaç, toplanan verileri ifade edebilecek kavramlara ve ilişkilere ulaşmaktır (Yıldırım ve Şimşek, 2018: 73). Öğretmen adaylarıyla yapılan görüşmeler sonucunda elde edilen veriler NVIVO 11 nitel veri analiz programıla değerlendirilmiştir. Katılımcıların ifadeleri doğrultusunda aynı içerikle ilgili olan veriler kodlanmış ve aynı olan kodlar bir araya getirilerek yükleme sayıları belirlenmiştir. Daha sonra veriler uzman tarafından da kodlanmış ve çalışmanın güvenirliğini sağlamak için uzmanın yaptığı kodlamalar ile araştırmacının yaptığı kodlamalar karşılaştırılmıştır. Uzman, 4 kategoride araştırmacıyla aynı görüşte olmamıştır. Miles ve Huberman'ın (1994/2019) güvenirlik formülüne göre (güvenirlik = görüş birliği sayısı / toplam görüş birliği + görüş ayrılığı sayısı) araştırmanın güvenirliği hesaplanmıştır ve araştırmanın güvenirliğinin \% 94 olduğu belirlenmiştir. Nitel çalışmalarda, uzman ve araştırmacı değerlendirmeleri arasındaki uyumun $\% 90$ ve üzeri olduğu durumlarda yeterli düzeyde bir güvenilirlik sağlanmış olmaktadır 
(Saban, 2009: 288). Uzman görüşlerinden sonra ise veriler model halinde sunulmuştur.

Çalışmada genel olarak güvenirlik ve geçerliği sağlamak için bazı stratejiler uygulanmıştır. İnandırıcılığı sağlamak için katılımcılar ile uzun süreli etkileşim sağlanmıştır. Çalışmanın her aşamasında alanında uzman kişilerden çalışmaya dair dönütler alınmıştır. Katılımcılarla yapılan görüşmeler sonucunda araştırmacı, aldığ1 notları katılımcıya özetleyerek katılımc1 teyidi yapılmıştır. Doğrudan alıntılar, araştırmacının yorumunu içermeden ayrıntılı betimlemeye uygun olarak verilmiştir. Son olarak tutarlılık incelemesi yapılarak çalışmaya farklı bir gözle bakılmış ve araştırmacının araştırma etkinliklerinde tutarlı davranıp davranmadığını ortaya konulmaya çalışılmıştır (Yıldırım ve Şimşek, 2018: 277-285).

\section{BULGULAR}

Sosyal bilgiler öğretmen adaylarının TGDÇY becerisine ilişkin görüşlerinin belirlenmesinin amaçlandığ 1 bu araştırmada, çalışmanın amacına yönelik altı alt amaç belirlenmiştir. Çalışmanın amacı ve alt amaçlar aşağıdaki modelde yer almaktadır.

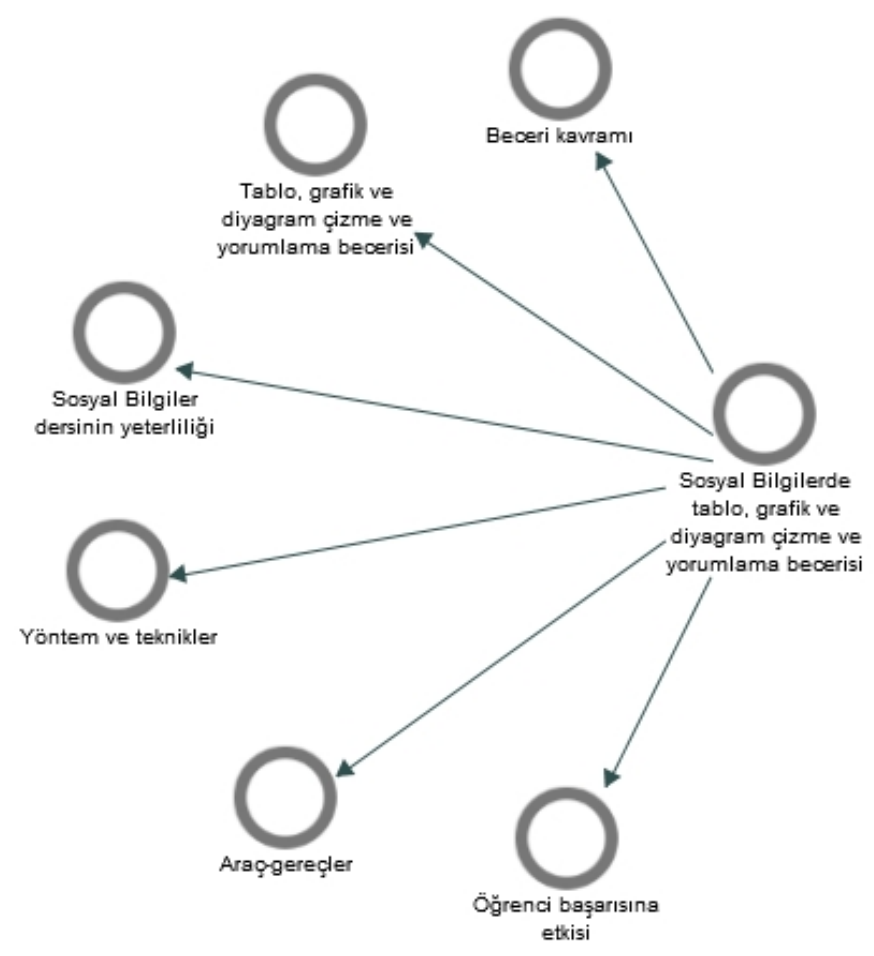


Şekil 1. Sosyal Bilgilerde TGDÇY Becerisine İlişskin Model

\section{Beceri Kavramının Tanımlanmasına İlişkin Görüşlere Yönelik Bulgular}

İlk alt amaçta öğretmen adaylarının beceri kavramı hakkındaki bilgilerine ulaşabilmek için "Beceri kavramını nasıl tanımlarsınız?" diye sorulmuştur. Öğretmen adaylarının bu soruya verdikleri cevaplar doğrultusunda yapılan kodlamalar ve yükleme sayıları aşağıdaki modelde yer almaktadır.

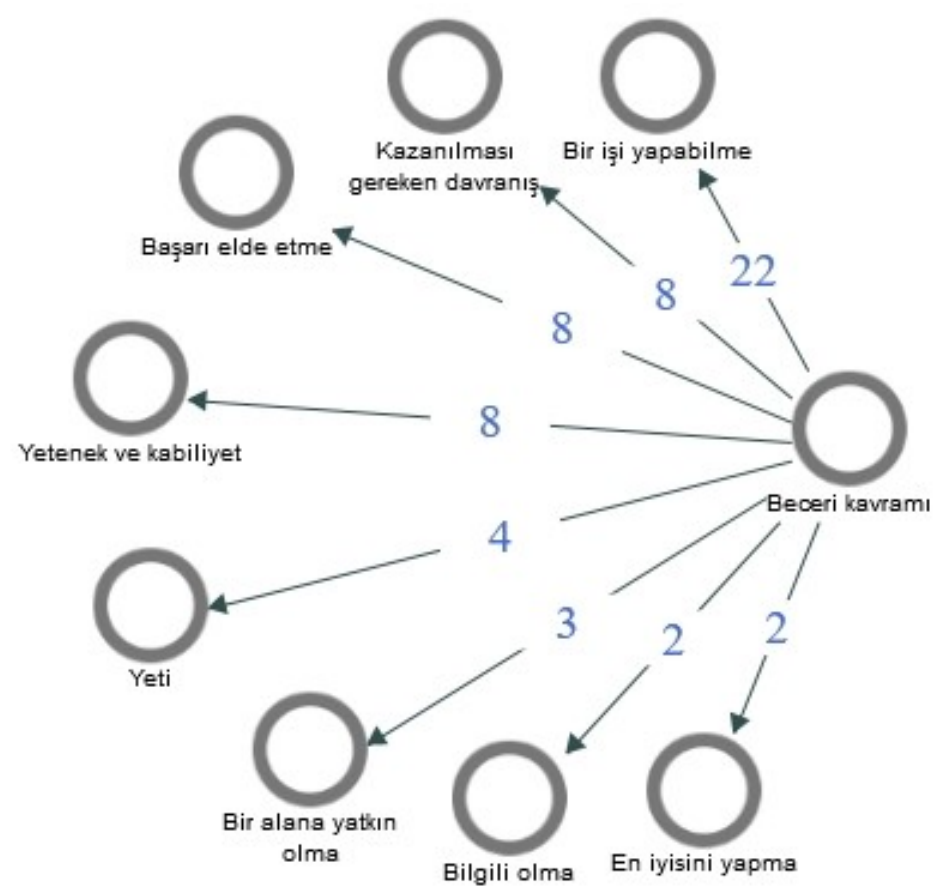

Şekil 2. Beceri Kavramının Tanımlanmasına İlişkin Model

Şekil 2. incelendiğinde öğretmen adayları çoğunlukla beceri kavramını bir işi yapabilme olarak tanımlamışlardır. Bu görüşlerini; Ö.A. 7 "eğitim öğretim süresince öğrencilere kazandırılması öngörülen, programın gerektirdiği etkinlikleri ve uygulamaları yapabilme yeteneği", Ö.A. 24 "farklı alanlarda bir şeyler yapabilme, amaca uygun olanı gerçekleştirebilme olgunluğuna erişebilme" , Ö.A. 25 "bir şeyi yapabilecek durumda olma" ve Ö.A. 42 "bir yaş grubu öğrencisinin kendisinden beklendik her türlü gelişimsel görevi sorunsuz olarak yerine getirebilmesi" şeklinde cevaplar veren öğretmen adayları beceri kavramını kişisel gelişimine bağlı olarak bireyden beklenen etkinlikleri ve işleri yapabilmeleri olarak açıklamışlardır. 
Öğretmen adaylarına göre beceri kavramının bir diğer tanımı ise kazanılması gereken davranıştır. Bu soruya; Ö.A. 31 "alınan eğitim sonrasında kazanılması gereken davranış", Ö.A. 35 "öğretim süreci içerisinde öğrenciye kazandırılması gereken davranışlar", Ö.A. 37 "öğrenciye bir etkinlik sonunda kazandırılması istenen davranışlar" ve Ö.A. 38 "insanların doğuştan veya sonradan öğrenme yoluyla kazandığı davranış ve eylemler bütünü” şeklinde cevaplar veren ögretmen adayları bu kavramı bireyin doğuştan sahip olduğu ya da eğitim ve öğretim süreci içinde öğrenciye kazandırılması hedeflenen eylemler olarak ifade etmişlerdir.

\section{TGDÇY Becerisinin Tanımına İlişkin Görüşlere Yönelik Bulgular}

TGDÇY becerisi hakkında öğretmen adaylarının bilgi sahibi olup olmadıklarını belirlemek amacıyla "TGDÇY becerisini nasıl tanımlarsınız?" sorusu sorulmuştur. Öğretmen adaylarının verdikleri cevaplar sonucunda yapılan kodlamalar ve yükleme sayıları aşağıdaki modelde gösterilmiştir.

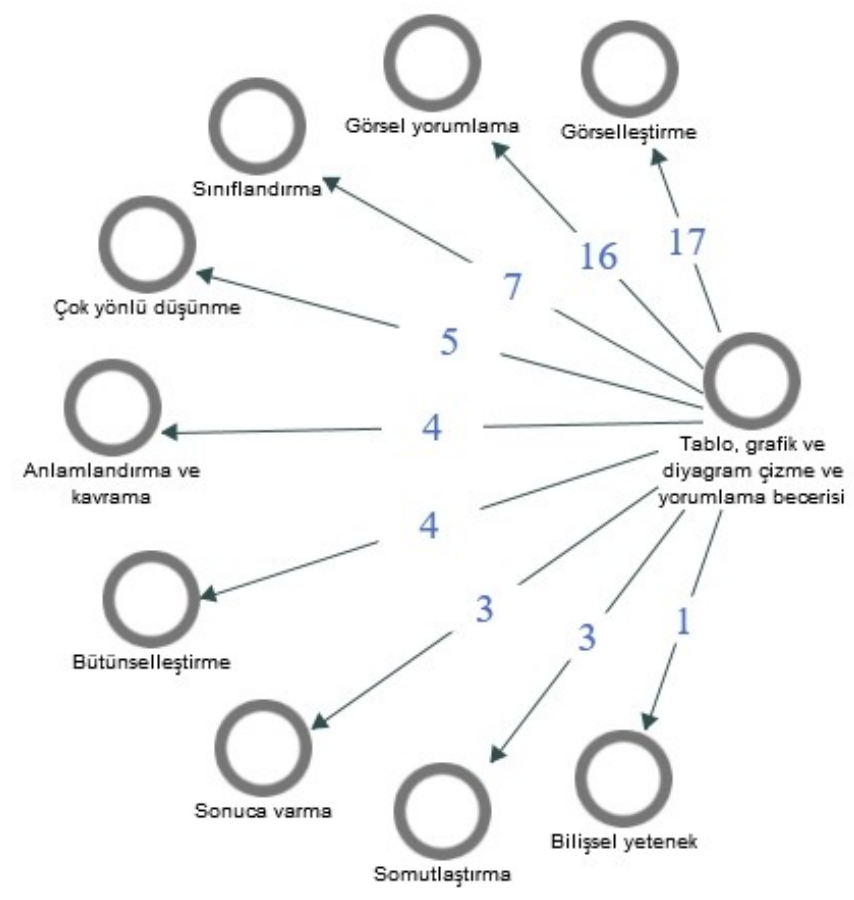

Şekil 3. TGDÇY Becerisinin Tanımlanmasına İlişkin Model

Öğretmen adaylarının birçoğu bu beceriyi görselleştirme olarak ifade etmişlerdir. Ö.A. 15. bu görüşünü; "öğrencilerin kendini hem sözel hem de 
görsel olarak ifade etme biçimi”" şeklinde belirtirken Ö.A. 19. "okunan, anlaşılan ve bilinen bir şeyin görsel bir şekilde ifade edilmesi”, Ö.A. 20 "bireyde bulunan, sayısal verileri ve bir durumu ya da olayı görsel şekillerle ifade edebilme", Ö.A. 22 "bir durumu ya da olayı tablo, grafik ve diyagram gibi görsel araçlar halinde gösterme", Ö.A. 30 "sayısal verilerin çizgilerle ifade edilmesi", Ö.A. 44 "soyut kavramların ve sayısal verilerin sade, anlaşılır ve etkileyici bir şekilde görsel araçlara aktarılması" ve Ö. A. 45 ise "karmaşı ve fazla bilgi birikimini en alt seviyeye indirmek ve kolay anlaşılması yönünden kullanılan şematik ifade biçimi” şeklinde belirtmiş̧tir. Öğretmen adayları genel olarak bu beceriyi sayısal ve sözel bilgilerin, bir durumun ya da bir olayın akışının görsel araçlar ile ifade edilmesi olarak açıklamışlardır.

Yine bu beceri hakkında tanımları sorulduğunda öğretmen adayları tarafından verilen cevapların çoğu görsel yorumlamadır. Ö.A.2 bu beceriyi "tablo, grafik ve diyagram gibi görsellerle karşılaşıldığında onlardan anlam çıkarabilme" olarak açıklarken Ö.A. 13 "görsel olarak ifade edilen bilgilerin yorumlanarak anlatılması", Ö.A. 15 "tablo, grafik ve diyagram gibi görsellerle bir konunun daha belirgin bir şekilde anlamlandırılması", Ö.A. 17 "şekillerden yola çıkarak bir konu hakkında düşünceleri belirtme biçimi", Ö.A. 20 "görsel şekillerin ne ifade ettiğini açıklayabilme", Ö.A. 40 "sınıflandırılmış verileri yorumlama durumu" ve Ö.A. $\mathbf{5 0}$ ise "veriler neticesinde elde edilen bilgileri açılkayabilme" olarak açıklamıştır. Bu görüşte olan öğretmen adaylarının söz konusu beceri hakkındaki genel fikri, bir görsel ile karşılaştığında ondan anlamlı bir şekilde yorum çıkarabilmek ve görselin anlatmak istediğinin anlaşılabilmesidir.

\section{Sosyal Bilgiler Dersinin TGDÇY Becerisini Kazandırma Konusunda Yeterliliğine İlişkin Görüşlere Yönelik Bulgular}

Bu beceri sosyal bilgilerde olduğu gibi coğrafya, fen bilimleri ve matematik gibi derslerde de yer aldığı için öğrenciler tarafından kazanılması büyük önem taşımaktadır. $\mathrm{Bu}$ yüzden sosyal bilgiler dersinin bu beceriyi kazandırma konusunda yeterli olup olmadığ 1 hakkında öğretmen adaylarının fikirlerini öğrenmek amacıyla "Sosyal bilgiler dersi TGDÇY becerisini kazandırma konusunda yeterli midir?" sorusu sorulmuştur. Öğretmen adaylarının verdiği cevaplar neticesinde yapılan kodlamalar ve yükleme sayılarına aşağıdaki modelde yer verilmiştir. 


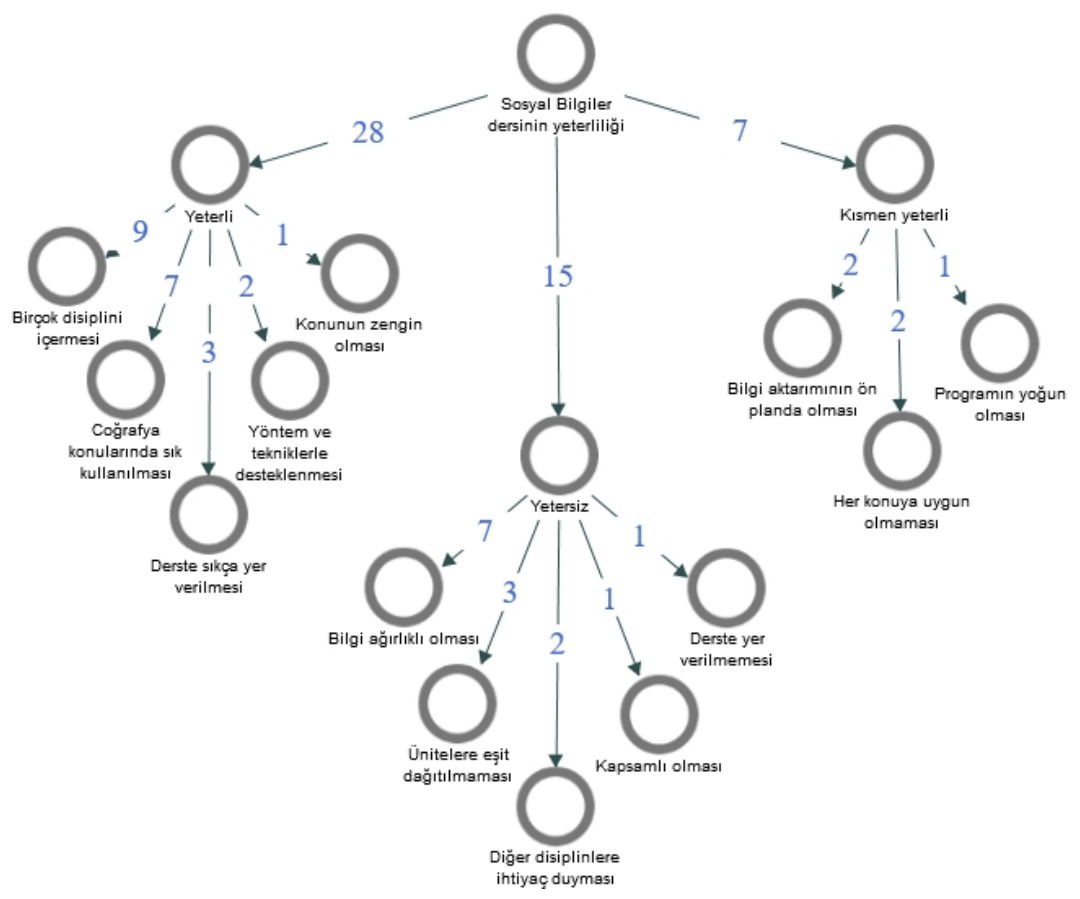

Şekil 4. Sosyal Bilgiler Dersinin TGDÇY Becerisini Kazandırma Konusunda Yeterliliğine İlişkin Model

Öğretmen adaylarının birçoğu sosyal bilgiler dersinin bu beceriyi kazandırma konusunda yeterli olduğunu ifade etmiştir. Bu görüşte olan öğretmen adaylarının büyük bir kısmı ise bu dersin birçok disiplini içermesinden dolayı yeterli olduğunu belirtmiştir. Ö.A. 1 "Gerek Coğrafya, gerek Tarih ve diğer disiplinlerin içinde çokça grafik ve tablo kullanımı görülmektedir. Sosyal Bilgiler dersi bundan dolayı bu beceriyi kazandırmaya müsaittir.", Ö.A. 19 "Sosyal Bilgilerde bu beceriyi kazandıracak birçok örnek vardır. Çünkü Sosyal Bilgiler; ekonomi, tarih, coğrafya, vb. birçok disiplin alanından faydalandığı için bunlarda grafik, tablo ve diyagramlar çok daha rahat kullanılır ve beceri olarak da öğrenciye kazandırılabilir.", Ö.A. 24 "Sosyal bilgiler farklı disiplinlerden faydalandığı için bu becerilerin öğrencilere kazandırılmasının kolay olduğunu düşünüyorum.", Ö.A. 25 "Sosyal bilgiler birç̧ok disiplinden bir araya gelmiş bir ders olduğundan bu beceri çok rahat kazandırılabilir." ve Ö.A. 48 "Sosyal Bilgiler dersinin tablo, grafik ve diyagram çizme ve yorumlama konusunda uygun olduğunu düşünüyorum. Çünkü dersin içeriğine baktığımızda Tarih, Coğrafya gibi disiplinler dikkate alınırsa birçok konuda tablo, grafik ve diyagram 
hazırlanabileceği taraftarıyım.” şeklinde cevap veren öğretmen adayları sosyal bilgiler dersinin coğrafya, tarih ve ekonomi gibi birçok bilim dalından oluşmasından dolayı tablo, grafik ve diyagramlara çokça yer verilecek imkânın olduğunu ve bu sayede bu becerinin rahat bir şekilde kazandırılabileceğini ifade etmişlerdir.

Öğretmen adaylarının bir kısmı da sosyal bilgiler dersinin bu beceriyi kazandırma konusunda yetersiz olduğunu ifade etmiştir. Yetersiz olduğunu ifade edenlerin birçoğunun gerekçesi ise bu dersin bilgi ağıllıklı olduğunu düşünmeleridir. Ö.A.4 "Genelde ders kitaplarında ve ders esnasında tablo ve grafiklerden çok bilgi yüklemesi ve paragraflara yer veriliyor.” Ö.A. 23 "Sosyal Bilgiler dersinin içeriğine baktığımız zaman daha çok sözel bilgiler ağırlıktadır.", Ö.A 36 "Ders içeriği olarak daha çok sözel konuların işlenmesi ve buna göre hareket edilmesi bu becerilerin kazandırılmasında yeterli değildir." ve Ö.A. 26 "Dersin içeriği daha çok sözel ağırlıklı olup tablo, grafik vs görsel araçlar yetersiz kalmaktadır. Bilgi aktarımı ön plandadır. Bu nedenle öğrencilere yorumlama becerisi kazandırmamaktadır.” gibi açıklama yapan öğretmen adayları tarafından sosyal bilgiler dersinin sözel bilgi ağırlıklı olmasından dolayı bu araçlara yer verilmediği ve genellikle düz anlatımın tercih edilmesinin bu beceriyi kazandırma konusunda yetersiz kalmasına neden olduğu ifade edilmiştir.

Öğretmen adaylarının bir kısmı ise sosyal bilgiler dersini bilgi aktarımının ön planda olmasından dolayı bu beceriyi kazandırma konusunda kısmen yeterli bulmuştur. Ö.A. 3 "Sosyal Bilgiler dersinin bu beceriyi kazandırma konusunda yeterli olduğu ve yeterli olmadığı durumlar vardır. Buna neden olan ise görsel öğelerden çok, bilgi aktarımına yer vermesidir. Bu görsellere daha çok yer verilirse hem sözel ağırlıklı olmaktan çıkar hem de bu beceri geliştirilir." ve Ö.A. 42 "Bana göre Sosyal Bilgiler dersi bilgi ağırlıklı bir ders olduğu için bu beceriyi kazandırma konusunda tamamen yeterli değildir. Aslında bu bilgiler görsellerle desteklense yoğunluk azalabilir ve yeterli olur." ş̧eklinde cevap veren öğretmen adayları bu dersin bilgi ağırlıklı olmasından dolayı görsel araçlara daha çok yer verilmesi gerektiği ancak bu araçlara yeterince yer verilmediği şeklinde görüşlerini ifade etmişlerdir.

\section{TGDÇY Becerisi Kazandırılırken Kullanılabilecek Yöntem ve Tekniklere İlişkin Görüşlere Yönelik Bulgular}

$\mathrm{Bu}$ beceriyi kazandırırken kullanılabilecek yöntem ve tekniklerin neler olduğunu belirlemek amacıyla öğretmen adaylarına "TGDÇY becerisi kazandırılırken kullanılabilecek yöntem ve teknikler nelerdir?" sorusu sorulmuştur. Öğretmen adaylarının bu soruya verdikleri cevaplardan yola çıkarak oluşturulan kodlar ve yükleme sayıları aşağıdaki modelde gösterilmiştir. 


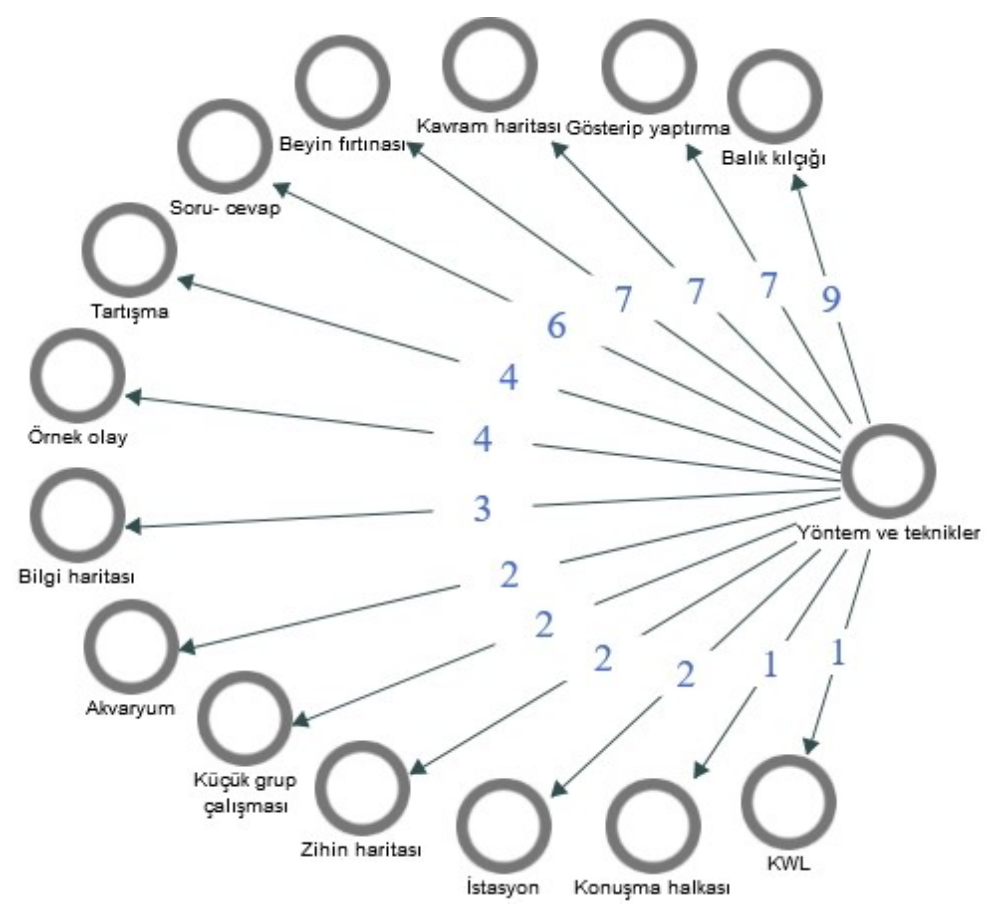

Şekil 5. TGDÇY Becerisi Kazandırılırken Kullanılabilecek Yöntem ve Tekniklere İlișkin Model

Öğretmen adayları bazı yöntem ve teknik kullanılarak bu becerinin kazandırılabileceğini ifade etmişlerdir. Bu yöntem ve tekniklerden en çok tercih edilen ise balık kılçığıdır. Öğretmen adaylarının verdikleri bu cevaplar genellikle diyagram çizme ve yorumlamaya yöneliktir. Ö.A. 13 "Bir savaşın ortaya çıkış nedenleri ve sonuçları balık kılçığı kullanılarak çizdirilip daha sonra yorumlatılabilir.", Ö.A. 27 "Bilgi ağırlıklı bir konu balık kılçığına dönüştürerek ögrencilerle birlikte yorumlanabilir. Bu sayede hem ders eğlenceli hale gelecektir hem de görsel olduğu için kalıcılık artacaktır.", Ö.A. 43 "Örneğin; bir tarihi olay anlatımı sırasında balık kılçığı diyagramı kullanılarak olayın neden-sonuç ilişkisi ile açıklanmasıyla bilgi kalıcılığı oluşabilir." ve Ö.A. 49 "Balık kılçığı tekniği kullanılarak konuyla ilgili bir sorunun, problemin nedenleri ve alt nedenlerini tanımlamak amacıyla balık kılçı̆̆ ile diyagram çizme ve yorumlama becerisi kazandırabilir." gibi cevaplardan da anlaşılacağı üzere öğretmen adayları olaylar arasındaki neden- sonuç ilişkisini göstermesi gibi avantajları olan balık kılçığı diyagramının, bilginin ön planda olduğu konuları görselleştirilerek hem 
öğrencilerin dikkatlerini çekeceğini hem de kalıcı öğrenmeyi sağlayacağını savunmuşlardır.

Öğretmen adaylarının verdikleri cevaplardan bir diğeri ise gösterip yaptırma tekniğidir. Ö.A. 1 "Güncel bir konu önce öğretmen tarafından çizilip sonra öğrencilerle birlikte tamamlanabilir. Daha sonrada hep birlikte tablo üzerinden yorumlama yaptırılabilir.", Ö.A. 11 "Bir tablo, diyagram vs. verilmeden önce öğrencinin anlayabilmesi için öğretmenin yorumlaması ve daha sonra öğrenciden çizmesini ve yorumlamasını istemek daha doğru olur.” ve Ö.A. 14 "Öğretmen önce kendi örnek tablo ya da grafik hazırlayıp yorumlamalı ve daha sonradan öğrenciden istemelidir.” gibi cevaplar veren öğretmen adayları, öncelikle ögretmen tarafından bir konu hakkında tablo vs. çizilip yorumlanması ve daha sonra öğrencilere bu örnekten hareketle çizim ve yorumlama yaptırarak bu becerinin kazandırılabileceğini belirtmişlerdir.

\section{TGDÇY Becerisi Kazandırılırken Kullanılabilecek Araç- Gereçlere İlişkin Görüşlere Yönelik Bulgular}

Öğrencilere herhangi bir kavram veya beceri kazandırılırken öğretimin araç ve gereçler ile desteklenmesinin öğrenmeyi kolaylaştıracağını söyleyebiliriz. Bu becerinin de kazandırılmasında kullanılabilecek araç ve gereçlerin genel olarak neler olduğunu belirlemek amaciyla öğretmen adaylarına "TGDÇY becerisi kazandırılırken kullanılabilecek araç-gereçler nelerdir?" sorusu sorulmuştur. Öğretmen adaylarının verdikleri cevaplar doğrultusunda oluşturulan kodlar ve yükleme sayıları aşağıdaki modelde gösterilmiştir:

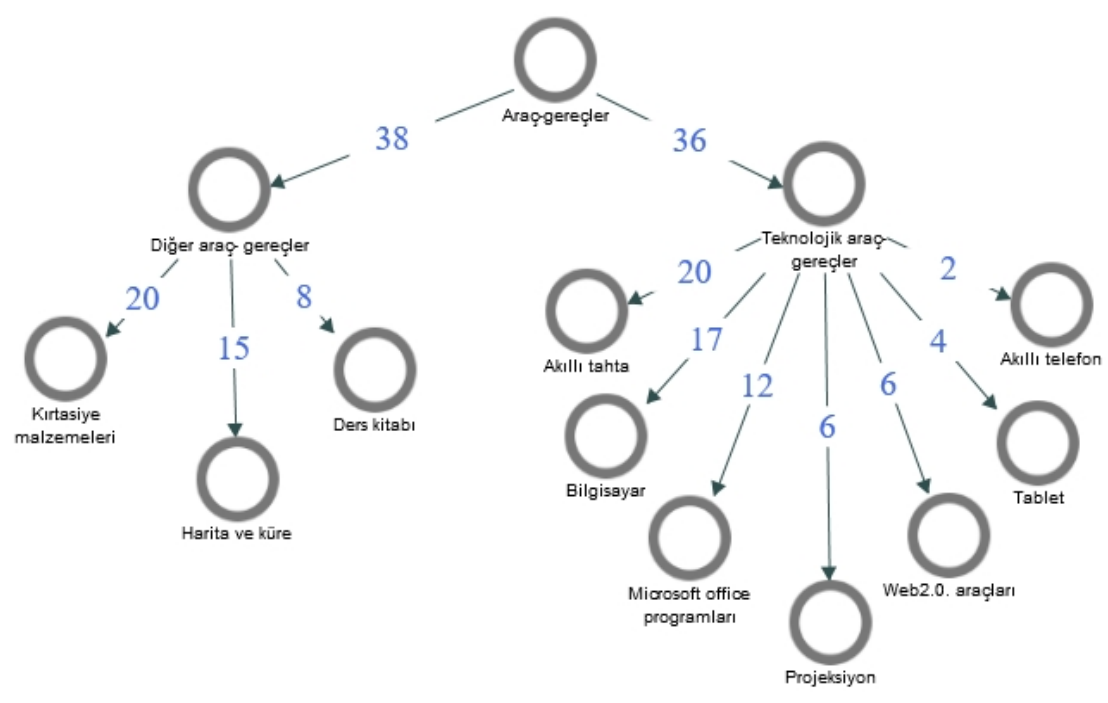




\section{Şekil 6. TGDÇY Becerisi Kazandırılırken Kullanılabilecek Araç- Gereçlere İlişkin Model}

Öğretmen adaylarının verdikleri cevaplardan yola çıkarak araç ve gereçler iki alt kategoriye ayrılmıştır. İlk alt kategoride kırtasiye malzemeleri ve ders kitabı gibi araç- gereçler yer alırken, ikinci alt kategoride ise akıllı tahta ve bilgisayar gibi teknolojik araç- gereçler yer almaktadır. İlk alt kategoride en çok tekrarlanan araç- gereç kırtasiye malzemeleridir. Genel olarak geleneksel araçları tercih eden öğretmen adaylarının cevapları arasında daha çok el becerisi kullanılarak oluşturulabilecek cetvel, renkli kalem, pergel, kâğıtt ve renkli karton gibi kırtasiye malzemeleri yer almaktadır. Bu cevaplar daha çok çizim becerisine yöneliktir. Ö.A. 16 "Cetvel ve boya kalemleriyle el becerilerine katkı sağlayarak çizimler yaptırılabilir.”, Ö.A. 37 “Öğrencilerin dikkatini çekmek için renkli kartonlar, el işi kâğıtları, renkli kalemler yardımıyla oluşturulacak tablo vs. ile konu özetlenebilir.”, Ö. A. 43 “Öğrenciyi bu beceri konusunda güdülemek için motive edici araç-gereçler olmalıdır. Bunlar grafikler ve tablo için cetvel, pergel olabilir. Onun dışında renkli kalemler yardımıyla daha eğlenceli ve ilgi çekici şekiller hazırlanabilir." ve Ö.A. $\mathbf{4 7}$ "Konuyu somutlaştırmak için kâğıt ve renkli kalemler ile birlikte öğrenciye çizim yaptırarak öğrenme desteklenebilir." şeklinde cevaplardan da anlaşılacağ 1 üzere öğretmen adayları tarafından kâğıt, kalem, renkli karton ve el işi kâğıtları gibi öğrencilerin dikkatini ve ilgilerini çekecek araçlar ile çizim yapmalarını sağlayarak öğrencilerin bu becerilerinin geliştirilebileceği ifade edilmiştir.

İkinci kategoride ise akıllı tahta, bilgisayar ve Microsoft Office programları gibi teknolojik araç- gereçler yer almaktadır. $\mathrm{Bu}$ araçlarla ilgili öğretmen adaylarının cevapları bir arada verilecektir. Ö.A. 14 "Excel gibi programlar üzerinden çok iyi grafik veya tablo hazırlanabilmektedir. Bu hazır tablolar sayesinde öğrencinin yorumlama becerisi geliştirilebilir.”, Ö.A. 33 "Teknolojiden çok güzel yararlanılabilir. Artık tahta üzerinde yapılan grafik ve tablolar yerine Microsoft Office programları kullanarak yapılan çalışmalar hem vakit açısından hem de öğrencinin ilgisini çekmesi bakımından daha kullanışlıdır.", Ö.A. 44 "Daha çok Web.2 araçları kullanılmalıdır. Eğitimin gelişimi için teknolojik gelişmeler iyi takip edilmeli, yeniliklere açık eğitim araç gereçleri ile becerilere yön verilmelidir." ve Ö.A. 46 “Tablo, grafik ve diyagramları bilgisayar programlarında hazırlayarak özellikle de diyagram üzerine resim, video ve küçük notlar ekleyerek zenginleştirilmiş bir materyal olarak sunulabilir." gibi cevaplarda da belirtildiği gibi öğretmen adayları teknolojinin sağladığı kolaylıkların dersler ile bütünleşmesini savunmuştur. Bilgisayar, projeksiyon ya da tablet gibi farklı araçlar belirtilse de hepsinin amacı ortaktır. Teknolojik uygulamalar sayesinde rahat ulaşılan dokümanlar aracılığıyla hem derste vakit kaybedilmeyeceği hem de etkili öğrenimin sağlanması savunulmuştur. 


\section{TGDÇY Becerisinin Öğrenci Başarısına Etkisine İlişkin Görüşlere Yönelik Bulgular}

$\mathrm{Bu}$ becerinin öğrenci başarısına etkisi hakkında öğretmen adaylarının görüşlerini öğrenmek amacıyla "TGDÇY becerisinin öğrenci başarısına etkisi nelerdir?" sorusu sorulmuştur. Öğretmen adaylarının verdikleri cevaplar doğrultusunda yapılan kodlamalar ve yükleme sayıları aşağıdaki modelde yer almaktadır.

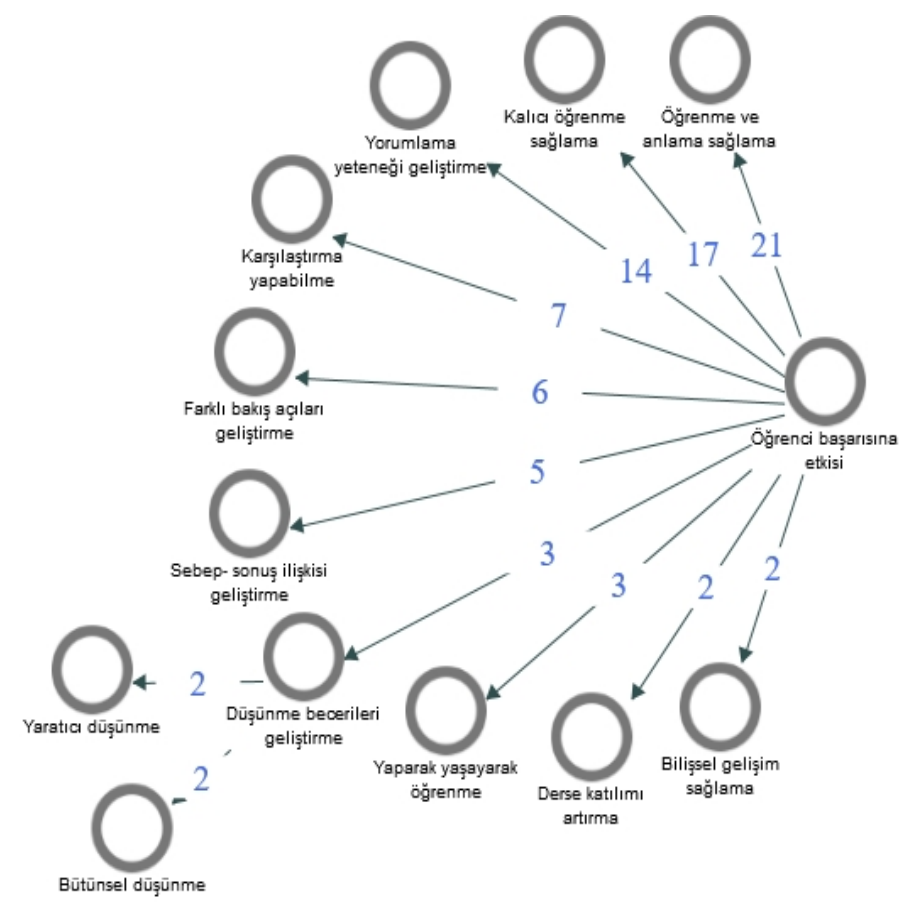

Şekil 7. TGDÇY Becerisinin Öğrenci Başarısına Etkisine İlişkin Model

Öğretmen adayları TGDÇY becerisinin öğrenci başarısına birçok alanda etki ettiğini ifade etmiştir. Birçoğu bu becerinin daha kolay öğrenme ve anlama sağladığını belirtmiştir. Ö.A. 3 "Öğrencinin çok yönlü düşünmesini sağlayarak konunun daha iyi öğrenilmesini ve kavranmasını sağlar.”, Ö.A. 14 "Öğrencinin üç boyutlu düşünme becerisini geliştirdiği için öğrenciler konuları daha iyi kavrar. Çünkü insanlar şekilleri ve görselleri kelimelerden daha iyi hatırlarlar ve öğrenirler.”, Ö.A. 21 "Konular arasındaki ilişki kolay sağlandığı için kısa sürede konunun içeriği öğrenciye aktarılır ve bu sayede öğrenme daha kolay 
gerçekleşir.", Ö.A. 47 "Sayısal verilerin somutlaştırılarak görsel olarak öğrencinin önüne sunulması sayesinde öğrenci karmaşık sayıları daha kolay bir şekilde kavrayabilir. Bu da konunun daha iyi anlaşılmasını sağlar.” Ö. A. 49 ise "Öğrenme sürecinde öğrenciler gerek sözel gerekse sayısal pek çok bilgiyi öğrenmeye çalışır. Öğrencilerin, öğrenmelerini kolaylaştırmak için eğitimöğretim sürecinde kullanılan görsel araçlar hem öğrencilerin ilgisini toplayarak derse güdüler hem de öğrenmeyi daha anlamlı hale getirir. Anlamlı öğrenme ve öğrenci başarısı arasında pozitif korelasyon vardır.” gibi cevaplarda da görüldüğü gibi öğretmen adayları görsel araçların öğrencilerin konuyu somut bir şekilde görmelerini sağlaması ve görselliğin ön planda olmasından dolayı öğrencilerin daha çok dikkatini çekmesi gibi durumların, öğrencilerin derse olan ilgisini artırmakla birlikte daha kolay anlama ve öğrenme sağladığını ifade etmişlerdir.

Öğretmen adaylarının bir diğer görüşü ise bu becerinin kalıcı öğrenmeyi sağladığıdır. Ö.A. 6 "Öğrenci öğrendiği şeyi görsel olarak belleğe aktardığı için bu bilgiler kalıcı olur.", Ö.A.13 "Öğrencinin bilgi düzeyini kalıcı bir boyuta ulaştırmasına ve öğrenilen bilgilerin daha sonra hatırlamasına yardımcı olur.", Ö.A. 19 "Görme ile öğrenmenin, duyma ile öğrenmeden daha etkili olması kalıcı öğrenmeyi sağlar." ve Ö.A. 37 "Ezbere dayalı yöntemi yok ederek bilgilerin daha kalıcı hale gelmesini sağlar. Öğrenilmek istenen konu görselleşir. Böylece öğrenilen şeyler hafızamızda daha uzun kalır.” gibi açıklamalar yapan öğretmen adayları genel olarak bu becerinin görsel zekâya hitap ettiği için bilginin kalıcı olmasını sağladığını ifade etmişlerdir.

\section{TARTIŞMA ve SONUÇ}

Geçmişten günümüze kadar bireylerin ihtiyaçları, teknolojide yaşanan gelişmelere paralel olarak değişikliğe uğramış ve sürekli bir artış içinde olmuştur. Bireylerin bu değişime ayak uydurabilmek için bir takım becerilere sahip olmaları gerekmektedir. Bu doğrultuda öğretim programları güncellenmekte ve çağın gereklilikleri doğrultusunda bireylerin sahip olması beklenen beceriler, öğretim programlarında yerini almaktadır. Araştırmanın sonuçlarına göre öğretmen adaylarının genel olarak beceri kavramını; bir işi yapabilme ve kazanılması gereken davranış olarak açıkladıkları belirlenmiştir. Öğretmen adaylarının birçoğunun, beceri kavramına ilişkin bilgi sahibi oldukları ve tanımlamaların TDK'nin tanımıyla tutarlı olduğu söylenebilir. Mutluer' in (2013) çalışmasında sosyal bilgiler öğretmenleri beceriyi benzer şekilde "iş yapabilme durumu" olarak açıklamaktadır.

Öğretmen adaylarının TGDÇY becerisi için genellikle sayısal verilerin, bir durumun ya da bir olayın görsellerle ifade edilmesi şeklinde tanımlamalar yaptıkları belirlenmiştir. Şahinkaya ve Aladağ'ın (2013) yaptığı çalışmada sınıf öğretmen adayları da benzer şekilde grafikleri; sayısal verilerin şekil, nesne ve 
sembollerle ifade edilmesi ve verilerin görsel düzende gösterimi şeklinde tanımlamışlardır. Benzer şekilde Durmuş ve Kuruyer'in (2019) sosyal bilgiler öğretmenleriyle yaptıkları çalışmada, öğretmenler bu beceriyi görselleştirerek kavrama, analiz ve yorumlama şeklinde ifade etmişlerdir.

$\mathrm{Bu}$ beceri, başka bir ifadeyle grafik düzenleyicileri hemen hemen tüm derslerde kullanılmaktadır. Sosyal bilgiler dersinde de önemli bir yere sahiptir. Sosyal bilgiler, birçok disiplini içeren ve bu sayede görsel araçların sıklıkla kullanılabileceği çeşitli alanlar doğuran bir derstir. Bu bakımından sosyal bilgilerin TGDÇY becerisini kazandırma konusunda yeterli bir ders olduğunu söylemek mümkündür. Öğretmen adaylarının birçoğuna göre de bu dersin söz konusu beceriyi kazandırma konusunda yeterli olduğu sonucuna ulaşılmıştır. Neden diye sorulduğunda ise öğretmen adayları bu dersin başta coğrafya olmak üzere birçok disiplini içermesinden dolayı bu görsel araçları kullanabilecek konu sayısının fazla olduğunu belirtmişlerdir. Yine öğretmen adaylarına göre başta nüfus konuları olmak üzere coğrafya konularında bu araçların kullanımının mümkün olduğu ve bu durumun söz konusu beceriyi geliştirme konusunda yeterli olacağı yönündedir. Bir kısım öğretmen adayı ise bu görüşe katılmamaktadır. Onlara göre bu araçlara sadece coğrafya konularında yer verilmekte ve ünitelerin hepsinde kullanılmamaktadır. Bu durumun ise bu beceriyi kazandırma konusunda yeterli olmayacağını ifade etmektedirler.

Bir konunun anlatımını kolaylaştırmak ve dersi tekdüze olmaktan kurtarmak için başvurulan ve oldukça fazla çeşidi olan öğretim yöntem ve tekniklerinin TGDÇY becerisinin öğretimini de destekleyeceği söylenebilir. Öğretmen adayları bu becerinin balık kılçı̆̆ 1 ve gösterip yaptırma gibi yöntem ve tekniklerle öğretilebileceğini ifade ettikleri belirlenmiştir. Bu yöntem ve tekniklere çok az sayıda öğretmen adayı değinirken yine yöntem ve teknik konusunda çeşitliliğin az olduğu sonucuna ulaşılmıştır.

Öğretmen adaylarının akıllı tahta ve bilgisayar gibi teknolojik araç- gereçlerle ve yine Microsoft Office ve Web 2.0. araçları ile teknolojinin sağladığ 1 kolaylıkları kullanarak bu becerinin kazandırılabileceğini ifade ederken bunun yanı sıra renkli kalem, kâğıt ve karton gibi kırtasiye malzemeleri ile öğrencilere çizimler yaptırıp, yaşayarak öğrenme sağlayarak bu becerinin kazandırılabileceğini ifade ettikleri belirlenmiştir. Görselliğin ön planda olduğu bu beceriyi kazandırırken başka araç ve gereçler ile anlatımı desteklemek öğrenmeyi kolaylaştırma açısından oldukça önemlidir. Öğretmen adaylarının TGDÇY becerisin kazandırırken kullanılabilecek araç-gereçlere ilişkin cevaplarının çeşitlilik gösterdiği ve bu beceriyi kazandırmaya fayda sağlayacă̆ 1 sonucuna ulaşılmıştır. Yine Durmuş ve Kuruyer'in (2019) sosyal bilgiler öğretmenleriyle yaptıkları çalışmada, akıllı tahta, bilgisayar ve kırtasiye malzemeleri aracılığıyla bu becerinin kazandırılabileceği belirlenmiştir. 
Dersin görsel araçlarla desteklenmesi öğrencilerin hem ilgisini çekmekte hem de derse olan ilgiyi artırmaktadır. Öğretmen adaylarının bu becerinin anlamayı kolaylaştırdığını ve kalıcı öğrenmeyi sağladığını ve yine bu becerinin karşılaştırma yapabilme ve yaparak yaşayarak öğrenme olanağı tanıdığını ve derse katılımı artırdığını ifade ettikleri belirlenmiştir. Benzer şekilde Dönmez, Yazıcı ve Sabancı'nın (2007) yaptıkları çalışmada, verilerin daha kolay anlaşılmasını, kalıcılığı, görselliği, verilerin somutlaştırılmasını sağladığı için öğretmen adaylarının grafik öğretimini faydalı buldukları tespit edilmiştir. Namal'ın (2011) yaptığı çalışmada, sosyal bilgiler derslerinin öğretiminde görsel materyallerden yararlanmanın; öğrencilerin başarısını artırdığı, derslere öğrencilerin aktif katılımını sağladığı ve soyut anlatımlara dayanan konuların öğretiminde görsel materyallerin kullanılmasının öğrencilerin konuları anlamasını kolaylaştırdığı belirlenmiştir. Şahinkaya ve Aladağ'ın (2013) yaptı̆̆ 1 çalışmada benzer şekilde sınıf öğretmen adayları tarafından grafiklerin; verilerin anlaşılmasını sağladığ1, kalıcılığı ve görselliği sağladığı, öğrenmeyi kolaylaştırdığ 1 ve bilgilerin karşılaştırılmasına olanak tanıdığ 1 sonucuna ulaşılmıştır. Hall, Kent, McCulley, Davis ve Wanzek'in (2013) yaptıkları çalışmada, grafik düzenleyicilerin soyut bilgileri somutlaştırmasına, karşılaştırma yapma, neden-sonuç ilişkilerini daha detaylı anlayabilme konusunda öğrencilere faydalı bir öğretim aracı olduğuna vurgu yapılmaktadır. Durmuş ve Kuruyer'in (2019) sosyal bilgiler öğretmenleriyle yaptıkları çalışmada, bu becerinin öğrenmeyi kolaylaştırdığg ve kalıcı öğrenmeyi sağladığ 1 sonucuna ulaşı1mıştır.

Sosyal bilgiler öğretmen adaylarının TGDÇY becerisine ilişkin görüşlerinin belirlenmesini amaçlayan bu çalışmada, öğretmen adaylarının genellikle söz konusu olan beceriye ilişkin teorik bilgiye sahip oldukları belirlenmiştir. Çalışmanın sonuçlarından yola çıkarak bazı önerilere yer verilmiştir. Öğretmen adaylarının beceri eğitiminde kullanılabilecek çeşitli yöntem ve teknikler konusunda daha fazla bilgi sahibi olmaları için beceri eğitimi verilirken yöntem ve teknikler ile beceri eğitimi desteklenmelidir. Bu çalışma sadece öğretmen adaylarının konuya ilişkin görüşlerini belirlemek ile sınırlı olduğu için pratikte öğretmen adaylarının bu beceriyi nasıl aktaracakları ya da tablo, grafik ve diyagramları çizme ve yorumlama düzeyleri bilinmemektedir. Daha sonraki aşamalarda sosyal bilgiler öğretmen adaylarının, tablo, grafik ve diyagramları çizme ve yorumlama düzeylerini belirlemek için çalışmalar yürütülebilir.

\section{KAYNAKÇA}

Akgün, İ. H. (2010). İlköğretim sosyal bilgiler 7. sinıf öğrencilerinin grafik okuma ve hazırlama becerisini kazanma düzeyleri [Yayımlanmamış yüksek lisans tezi]. Niğde Üniversitesi. 
Akın, Köse, M. (2011). Sosyal bilgiler ögretiminde istatistik ve grafik kullanım tekniklerinin ögrencilerin grafik okuma becerisine etkisi [Yayımlanmamış yüksek lisans tezi]. Gazi Üniversitesi.

Alverman, D. E. ve Boothby, P. R. (1986). Children's transfer of graphic organizer instruction. Journal of Reading Psychology, 7(2), 87-100.

Avcı, Y. ve Çelik, G. (2018). Ortaokul yedinci sınıf öğrencilerine görsel okuryazarlık becerisi etkinliklerinin uygulanması. Journal Of Awareness, 3 (Özel Say1), 697-714. https://doi.org/10.26809/joa.2018548681

Bayazıt, İ. (2011). Öğretmen adaylarının grafikler konusundaki bilgi düzeyleri. Gaziantep Üniversitesi Sosyal Bilimler Dergisi, 10(4), 1325-1346.

Bean, T., Singer, H., Sorter, J. and Frazee, C. (1986). The effect of metacognitive instruction in outlining and graphic organizer construction on students' comprehension in a tenthgrade world history class. Journal of Reading Behavior, 18(2), 153-169.

Büyüköztürk, Ş., Kılıç, Çakmak, E., Akgün, Ö. E., Karadeniz, Ş. ve Demirel, F. (2018). Bilimsel araştırma yöntemleri (25. Bask1). Pegem Akademi. https://doi.org/10.1427/97899449/9289

Casteleyn, J. and Mottart, A. (2012). Presenting material via graphic organizers in science classes in secondary education. Procedia - Social and Behavioral Sciences, 69, 458-466.

Cendek, M. E. (2015). Öğrencilerde harita okuryazarlı̆̆ının geliştirilmesine ilişkin sosyal bilgiler ögretmenlerinin görüşleri [Yayımlanmamış yüksek lisans tezi]. Marmara Üniversitesi.

Creswell, J. W. (2020). Nitel araştırma yöntemleri: beş yaklaşıma göre nitel araştırma ve araştırma deseni. Bütün M. ve Demir S. B. (Çev. Ed.), Siyasal Kitabevi. (Eserin aslının yayın tarihi 2013).

Çiltaş, A. (2011). Mutlak değer içeren denklem ve eşitsizliklerin öğretiminde grafik kullanımının etkinliği. Ahi Evran Üniversitesi Ĕ̆itim Fakültesi Dergisi, 12(3), 39-53.

Demirci, N. ve Uyanık, F. (2009). Onuncu sınıf öğrencilerinin grafik anlama ve yorumlamaları ile kinematik başarıları arasındaki ilişki. Necatibey Ĕgitim Fakültesi Elektronik Fen ve Matematik Eğitimi Dergisi, 3(2), 22-51.

Doğanay, H. (2002). Coğrafya ögrretim yöntemleri. Aktif Yayınevi. 
Dönmez, C., Yazıcı, K. ve Sabancı, O. (2007). Sosyal bilgiler derslerinde grafik düzenleyicilerinin kullanımının öğrencilerin akademik bilgiyi elde etmelerine etkisi. Türk Ĕgitim Bilimleri Dergisi, 5(3), 437-459.

Durmuş, E. ve Kuruyer, D. (2019, Kasım 7-9). Sosyal bilgiler ögretmenlerinin tablo, grafik ve diyagram çizme ve yorumlama becerisine ilişkin görüşleri [Sözlü sunum]. 8. Uluslararası Sosyal Bilgiler Eğitimi Sempozyumu, Ankara Üniversitesi Eğitim Bilimleri Fakültesi, Ankara. http://issse.org/wp-content/uploads/2019/12/ISSSE-2019-ProceedingBook.pdf

Ekiz, D. (2015). Bilimsel araştırma yöntemleri (4. Baskı). Anı Yayıncılık.

Erdoğan, E. (2019). Gözlem, İçinde Aksoy, B., Akbaba, B. ve Kılcan, B. (Eds.). Sosyal bilgilerde beceri eğitimi (1. Bask1) (ss. 200-218). Pegem Akademi. https://doi.org/10.14527/9786050370454

Gültekin, C. (2009). Ortaöğretim 9. sinıf öğrencilerinin çözeltiler ve özellikleri konusu ile ilgili grafik çizme okuma ve yorumlama becerilerinin incelenmesi [Yayımlanmamış yüksek lisans tezi]. Balıkesir Üniversitesi.

Gürgil, F. (2018). Table, graphic, and diagram interpretation and preparation skills: social studies and geography teachers' practice and beliefs, Review of International Geographical Education Online (RIGEO), 8(3), 517-541. https://doi.org/10.33403/rigeo.505266

Gürgil, F. (2019). Araştırma, İçinde Aksoy B., Akbaba B. ve Kılcan B. (Eds.). Sosyal bilgilerde beceri eğitimi (1. Baskı) (ss. 1-24). Pegem Akademi. https://doi.org/10.14527/9786050370454

Hall, C., Kent, S., McCulley, L., Davis, A. and Wanzek, J. (2013). A new look at mnemonic and graphic organizes in the secondary social studies classroom. Teaching Exceptional Children, 46(1), 47-55.

Karasar, N. (2020). Bilimsel araştırma yöntemi (35. Bask1). Nobel Yayın Dağıtım.

Keskin, G. (2018). Sosyal bilgiler dersinde grafik hazırlama ve okuma becerisine dayalı etkinliklerin akademik başarlya katkısının incelenmesi [Yayımlanmamış yüksek lisans tezi]. Aksaray Üniversitesi.

Meydan, A. ve Akdağ, H. (2015). Sosyal bilgiler dersinde öğretim teknolojileri ve materyal kullanımı, İçinde Tay B. ve Öcal A. (Eds.). Özel ögretim yöntemleriyle sosyal bilgiler ögretimi (4.Bask1) (ss. 154- 190). Pegem Akademi. 
Miles, M. B. ve Huberman, M. A. (2019). Genişletilmiş bir kaynak kitap: nitel veri analizi. Akbaba S. ve Ersoy A. (Çev. Eds.), Pegem Akademi. (Eserin aslının yayın tarihi 1994). https://doi.org/10.14527/9786053181415

MEB (2005). Sosyal Bilgiler 6. ve 7. Sınıf Öğretim Programı. (Alındığı tarih 03.03. 2019).

MEB (2016). PISA 2015 Ulusal Raporu. MEB Yayınları. https://odsgm.meb.gov.tr/test/analizler/docs/PISA/PISA2015_Ulusal_Ra por.pdf (25.03.2021 tarihinde erişilmiştir.)

MEB (2018a). Sosyal Bilgiler Dersi Öğretim Programı (İlkokul ve Ortaokul 4-7. Siniflar). $\quad$ http://mufredat.meb.gov.tr/ProgramDetay.aspx?PID=354 (31.03.2019 tarihinde erişilmiştir).

MEB (2018b). Ortaöğretim Coğrafya Dersi Öğretim Programı (9, 10, 11 ve 12. Siniflar). http://mufredat.meb.gov.tr/ProgramDetay.aspx?PID=336 (13.05.2019 tarihinde erişilmiştir.)

MEB (2019). PISA Türkiye Ön Raporu, MEB Yayınları. http://www.meb.gov.tr/meb_iys_dosyalar/2019_12/03105347_PISA_201 8_Turkiye_On_Raporu.pdf (25.03.2021 tarihinde erişilmiştir.)

Mutluer, C. (2013). Sosyal bilgiler programlarında yer alan beceriler hakkında sosyal bilgiler öğretmen görüssleri (İzmir Menemen örneği). Turkish Studies, 8(7), 355-362. https://dz.doi.org/10.7827/TurkishStudies.5236

Namal, R. (2011). İlkögretim 7. sinlf sosyal bilgiler dersinde yer alan “"ülkemizde nüfus" ünitesinin ögretiminde görsel materyallerden yararlanmanın ögrenci başarısı üzerine etkisi [Yayımlanmamış yüksek lisans tezi]. Atatürk Üniversitesi.

Namal, R. (2019). Tablo, grafik ve diyagram çizme ve yorumlama, İçinde Aksoy, B. Akbaba B. ve K1lcan B. (Eds.). Sosyal bilgilerde beceri eğitimi (1. Bask1) (ss. 517-536). Pegem Akademi. https://doi.org/10.14527/9786050370454

Oruç, Ş. ve Akgün, İ. H. (2010). İlköğretim sosyal bilgiler 7. sınıf öğrencilerinin grafik okuma becerisini kazanma düzeyleri. Uluslararası Avrasya Sosyal Bilimler Dergisi, 1(1), 51-58.

Öztaşkın, Bektaş, Ö. (2014). Grafik örgütleyicilerinin sekiz türü ile sosyal bilgiler öğretimi: akademik başarı ve başarı yönelimlerine etkisi. Uluslararası Avrasya Sosyal Bilimler Dergisi, 5(14), 83-109. 
Pala, Ş. M. ve Başıüyük, A. (2019). Matematik becerisinin sosyal bilgiler derslerindeki harita grafik ve tablo okuma becerilerine etkisi. Uluslararası Sosyal Bilgilerde Yeni Yaklaşımlar Dergisi, 3(1), 41-56.

Saban, A. (2009). Öğretmen adaylarının öğrenci kavramına ilişkin sahip oldukları zihinsel imgeler. Türk Eğitim Bilimleri Dergisi, 7(2), 281-326.

Safi, H. (2010). Sosyal bilgiler ögretim programında yer alan mekânı algılama becerisinin geliştirilmesi hakkında öğretmen görüşleri [Yayımlanmamış yüksek lisans tezi]. Marmara Üniversitesi.

Seferoğlu, S. ve Akbıyık, C. (2006). Eleştirel düşünme ve öğretimi. Hacettepe Üniversitesi Ĕgitim Fakültesi Dergisi, 36, 193-200.

Sönmez, Ö. F. ve Koç, H. (2017). Sosyal bilgiler öğretiminde harita, grafik ve tablo kullanımı, İçinde Sever R. ve Koçoğlu E. (Eds.), Sosyal bilgiler ögretiminde eğitim teknolojileri ve materyal tasarımı (2. Baskı) (ss. 181199). Pegem Akademi.

Şahin, S., Gençtürk, E. ve Budanur, T. (2007). Coğrafya öğretiminde uygun grafik seçimi ve kullanımının öğrenme üzerindeki etkisi. Kastamonu Ĕ̈itim Dergisi,15(1), 293-302.

Şahinkaya, N. ve Aladağ, E. (2013). Sınıf öğretmen adaylarının grafikler ile ilgili görüşleri. Adiyaman Üniversitesi Sosyal Bilgiler Enstitüsü Dergisi, 6(15), 309-328.

Taşdemir, A., Demirbaş, M. ve Bozdoğan, A. E. (2005). Fen bilgisi öğretiminde işbirlikli öğrenme yönteminin öğrencilerin grafik yorumlama becerilerini geliştirmeye yönelik etkisi. Gazi Üniversitesi Kırşehir Eğitim Fakültesi Dergisi, 6(2), 81-91.

Temiz, B. K. ve Tan, M. (2009). Lise 1. sınıf öğrencilerinin grafik yorumlama becerileri. Selçuk Üniversitesi Ahmet Keleşoğlu Eğitim Fakültesi Dergisi, 28, 31-43.

TDK Online Sözlük (2020). http://www.tdk.gov.tr/.

Türker, A. (2019). Değişim ve sürekliliği algılama, İçinde Aksoy B., Akbaba B. ve Kılcan B. (Eds), Sosyal bilgilerde beceri ę̆itimi (1. Bask1) (ss. 54-66). Pegem Akademi. https://doi.org/10.14527/9786050370454

Yanpar Şahin, T. ve Yıldırım, S. (1999). Öğretim teknolojileri ve materyal geliştirme. Anı Yayıncılık. 
Yayla, G. ve Özsevgeç, T. (2014). Ortaokul öğrencilerinin grafik becerilerinin incelenmesi: çizgi grafikleri oluşturma ve yorumlama. Kastamonu Eğitim Dergisi, 23(3), 1381-1400.

Yazıcı, K. (2006). Sosyal bilgilerde kullanılan görsel araçlar: haritalar-küreler, resimler, tablolar ve grafikler. Selçuk Üniversitesi Sosyal Bilimler Enstitüsü Dergisi, 15, 651-662.

Yıldırım, A. ve Şimşek, H. (2018). Sosyal bilimlerde nitel araştırma yöntemleri (11. Baskı). Seçkin Yayıncılık.

Zaini, S. H., Mokhtar, S. Z. and Nawawi, M. (2010). The effect of graphic organizer on students' learning in school. Malaysian Journal of Educational Technology, 10(1), 17-23.

Zorluoğlu, S. L. ve Türkmen, G. (2020). 8. Sınıf fen bilimleri dersi öğrencilerinin grafik okuma, yorumlama ve hazırlama beceri düzeylerinin incelenmesi. Yalvaç Akademi Dergisi, 5(1), 1-16. 